\title{
Psikolojik Sermayenin Görev ve Bağlamsal Performans Üzerindeki Etkileri: Polis Teşkilatında Bir Araştırma
}

\author{
The Effects of Psychological Capital on Task and Contextual Performance: A Research on \\ Police Organization
}

Sema POLATCI ${ }^{1}$

\begin{abstract}
ÖZET
Psikolojik sermayenin en önemli özelliklerinden birisi, iş performansı ve performansın öncülleri üzerinde etkin bir rol oynamasıdır. Bu nedenle bu çalışmada psikolojik sermaye kavramının bir bütün olarak ve alt boyutlarının (özyeterlilik, ümit, iyimserlik ve dayanıklılık) performans ve performans alt boyutları üzerindeki etkisini ortaya koymak amaçlanmıştır. Tokat il merkezinde görev yapan polislerden elde edilen veriler regresyon analizine tabi tutulmuştur. Sonuçlara göre toplam psikolojik sermaye performans üzerinde önemli ölçüde etkili olurken, psikolojik sermayenin tüm alt boyutları performans üzerinde aynı şekilde etkili olmamıştır. Psikolojik sermayenin alt boyutlarından sadece dayanıklılığın hem toplam performansı hem de iki performans boyutunu anlamlı ve pozitif yönde etkilediği, ümit alt boyutunun ise toplam performansı ve görev performansını anlamlı ve pozitif yönde etkilediği tespit edilmiştir.
\end{abstract}

Anahtar Kelimeler: Psikolojik sermaye, performans, görev performansı, bağlamsal performans

\section{GiRiş}

Sosyal bir sistem olan örgüt içerisindeki bireylerin daha olumlu şartlar ve daha iyi bir psikoloji ile çalışmalarına yardımcı olabilmek için pek çok araştırma yapılmıştır. Seligman (1998) öncülüğündeki bir grup tarafından psikolojinin yıllardır unutulan iki önemli misyonu; "insan yaşamını iyileştirmek" ve "üstün yeteneklerini geliştirmek" tekrar gün ışığına çıkarılmıştır. Bu sayede psikolojide yeni ve olumlu bir akım oluşmuş ve bu akıma "pozitif psikoloji" adı verilmiştir. Kavramın yaratıcısı olan Seligman, Csikszentmihalyi ile birlikte insanların olumlu yönlerini inceleyen bir bilim dalı olan pozitif psikolojinin odak noktasını ümit, bilgelik, yaratıcılık, ileri görüşlülük, cesaret, tinsellik ve sorumluluk gibi yaşamın içerisindeki olumlu özellikler olarak tanımlamışlardır (2000).

2000 'li yıllarda adından sıkça söz ettiren pozitif psikoloji, özellikle son yıllarda örgütsel davranış ve insan kaynakları alanlarındaki akademik ve uygulamalı

\begin{abstract}
One of the most important features of psychological capital is to play an effective role on performance and the antecedents of performance. Therefore this study was conducted to analyze howsub-dimensions of psychological capital (selfefficacy, hope, optimism and resilience) individually and as a composite higher-order factor predicted performance and sub-dimensions of performance. The data obtained fromthe policein the province ofTokatwere subjected toregression analysis. According to the results, total psychological capital affects total performance, task performance and contextual performance. From sub-dimensions of psychological capital only resilience affects total performance, task performance and contextual performance; and hope sub-dimension affects total performance and task performance.
\end{abstract}

Keywords: Psychological capital, performance, task performance, contextual performance

faaliyetlerde sıkça kullanılmaktadır. Pozitif psikolojiye karşı gelişen bu yoğun ilgi, örgütsel davranış alanında da pozitif bir bakış açısına ihtiyaç duyulmasına neden olmuş ve 2002 yılında Luthans tarafından pozitif örgütsel davranış kavramı geliştirilmiştir. Luthans (2002a) kavramı "günümüz iş ortamlarının performansını artırmak için insan kaynaklarının güçlü yönleri ve psikolojik kapasitesi üzerindeki çalışma ve uygulamalar" şeklinde tanımlamaktadır. Gerçekte iş hayatında pozitif ve negatif durumlar/ olaylar/deneyimler, birbirleriyle iç içe geçmiş şekilde bulunmaktadırlar. Bu nedenle pozitifliğe çok fazla odaklanıp, negatif durumları gözardı etmek doğru değildir. Pozitif örgütsel davranış pozitif ve negatif faktörleri en uygun şekilde harmanlayarak, insan kaynağını geliştirmeyi ve bu sayede örgütsel performansı artırmayı amaçlamaktadır. Dolayısıyla pozitif örgütsel davranış alanındaki araştırma ve uygulamalar da, bu denge mantığı çerçevesinde yürütülmektedir (Polatcl, 2011: 25). 
Pozitif örgütsel davranış kavramını, diğer pozitif kavramlardan ayıran bazı özellikler bulunmaktadır. Kavram bu özellikleri sayesinde literatürdeki diğer pozitif yaklaşımlardan, davranışın pozitif başlıklarından, pozitif psikolojiden ve örgütü inceleyen pozitif bir bilim olan pozitif örgütsel bilimden (positive organizational scholarship) ayrılmaktadır (Luthans ve Avolio, 2009). Pozitif örgütsel davranışın özellikleri teori ve uygulamaya dayanıyor olması, geçerliliği olan ölçüm araçlarına sahip olması, durum temelli olması, birey düzeyinde iş performansı ve tatminine pozitif etki yapması ve örgütsel davranış alanında eşsiz olması olarak sıralanabilmektedir (Luthans, 2002a; b; Luthans, Youssef, Avolio, 2007).

Pozitif örgütsel davranış kavramı sahip olduğu bu temel özellikler dolayısıyla, psikolojik unsurların ölçülebilmesi, geliştirilebilmesi ve yönetilebilmesini zorunlu kılmıştır. Bu durum ise örgütlerin ölçmek, geliştirmek ve yönetmek üzere odaklandıkları sermaye türleri olan ekonomik, beşeri ve sosyal sermayeden daha fazlasına ihtiyaç duymalarına ve geleneksel sermaye türlerine ek olarak "psikolojik sermaye" kavramının literatüre girmesine neden olmuştur (Larson ve Luthans, 2006).

Literatürde psikolojik sermayenin performans üzerindeki etkisini araştıran çalışmalar bulunmaktadır. Ancak teori ve uygulamada iki tür performanstan bahsedilmektedir. Bireysel performansı tanımlayan bu iki performans alt boyutu, görev performansı ve bağlamsal performans olarak ifade edilmektedir. Görev performansı bir işin yerine getirilmesi gereken temel sorumluluklarını ifade eder ve içeriği bir işten diğerine göre değişmektedir (Jawahar ve Carr, 2007). Bağlamsal performans ise, görev performansını destekleyen psikolojik ve sosyal bağlamın sürdürülmesi ve artırılmasına katkı sağlayan davranışlardır (Borman ve Motowidlo, 1993; Motowidlo, 2000).

Kamu düzenini ve vatandaşların can ve mal güvenliğini ve temel hak ve özgürlüklerini korumakla görevli, yasa uygulayıcı bir kamu görevlisi olan polislerin işlerinde başarıları, tüm ülkeyi etkilemektedir. Polislerin işteki başarıları, onların görev ve bağlamsal performanslarının yüksekliği ile ilişkilidir. Bu çalışmada tehlikeli, zor ve çok fazla fedakarlık isteyen bir meslek icra eden polislerin psikolojik sermaye düzeylerinin performansın iki alt boyutu üzerindeki etkisi ayrı ayrı incelenmiştir. Aynı zamanda görev ve bağlamsal performans üzerine psikolojik sermayenin alt boyutlar bazındaki etkisi de araştırılmıştır.

\section{LITTERATÜR}

\subsection{Psikolojik Sermaye Kavramı}

Psikolojik sermaye genel itibariyle "kim olduğumuz" ve "pozitif gelişim sayesinde ne olabileceğimizi" ifade etmektedir (Luthans, Youssef, Avolio, 2007: 20). Bu açıdan baktığımızda neye sahip olduğumuzla ilgilenen ekonomik sermaye, ne bildiğimizle ilgilenen beşeri sermaye ve kimleri tanıdığımıza odaklanan sosyal sermayeden ayrılmaktadır (Luthans,Luthans, Luthans, 2004). Envick (2005) geleneksel sermaye türlerinden hareketle psikolojik sermayeyi "bireyin verimlilik amacıyla ekonomik, beşeri ve sosyal sermayeleri başarılı bir şekilde örgüte taşıyabilme yeteneği" olarak tanımlamaktadır.

İnsan kaynaklarının anlaşıması ve yönetilmesi konusunda, psikolojik sermaye yeni bir bakış açısı ve yaklaşım getirmektedir. Bu bakış açısını diğer yaklaşımlardan ayırt edebilmek için psikolojik sermayenin sahip olduğu bazı özellikler vardır. Bu özellikler ( $\mathrm{Nel}-$ son ve Cooper, 2007: 11):

- Psikolojik sermaye, beşeri sermayeden daha fazlasını ifade etmektedir.

- Psikolojik sermaye, sosyal sermayeden daha fazlasını ifade etmektedir.

- Psikolojik sermaye pozitiftir.

- Psikolojik sermaye eşsizdir.

- Psikolojik sermaye teori ve araştırma tabanlıdır.

- Psikolojik sermaye ölçülebilirdir.

- Psikolojik sermaye durum temellidir, bu nedenle geliştirilebilirdir.

- Psikolojik sermaye iş performansı üzerinde etkilidir.

Modern örgüt yapıları içerisinde kullanılmaya başlayan psikolojik sermayenin sahip olduğu özellikler incelendiğinde, kavramın şimdiye kadar geliştirilmiş olan kavramların tamamından farklı olduğu ortaya çıkmaktadır. Pozitif psikolojinin örgütsel davranış alanındaki yansıması olan pozitif örgütsel davranış içerisinde geliştirilmiş olan psikolojik sermaye kavramı, özellikle rekabet üstünlüğü ve iş performansına yaptığı ciddi katkılar dolayısıyla büyük önem taşımaktadir (Polatcl, 2011: 43).

Psikolojik sermaye ile performans arasındaki ilişki pek çok araştırmaya konu olmuştur. Araştırmalar psikolojik sermayenin hem boyutlar bazında (özyeterlilik, ümit, iyimserlik ve dayanıklıık), hem de toplam psikolojik sermaye bazında iş performansı üzerinde anlamlı etkisinin olduğunu göstermektedir (Luthans, Avolio, Walumbwa, vd., 2005; Luthans, Youssef ve 
Avolio, 2007: 19; Luthans, Norman, Avolio, vd., 2008; Youssef ve Luthans, 2007; Rego, Marques, Leal, vd., 2010; Luthans, Avolio, Avey, vd., 2007; Akdoğan ve Polatcı, 2013).Bu çalışmada polislerin sahip oldukları psikolojik sermaye düzeyinin toplam performansı, görev performansını ve bağlamsal performansı nasıl etkilediği araştırılmak istenmiş ve bu nedenle aşağıdaki hipotezler geliştirilmiştir.

Hipotez 1a: Polislerin genel psikolojik sermaye düzeyleri toplam performansı pozitif yönde etkilemektedir.

Hipotez 1b: Polislerin genel psikolojik sermaye düzeyleri görev performansını pozitif yönde etkilemektedir.

Hipotez 1c: Polislerin genel psikolojik sermaye düzeyleri bağlamsal performansı pozitif yönde etkilemektedir.

\subsection{Psikolojik Sermayenin Boyutları}

Psikolojik sermaye alanında yapılmış olan araştırmalar sonucunda, pozitif psikoloji içerisindeki dört kapasitenin psikolojik sermayenin özelliklerini en iyi şekilde tanımladığına karar verilmiştir. Bu kapasiteler psikolojik sermayenin boyutları olarak kabul edilmiştir (Nelson ve Cooper, 2007:13). Aşağıda psikolojik sermayenin dört boyutu ve bunların tanımlarına yer verilmiştir.

Özyeterlilik: Kavramın temeli, Sosyal Bilişsel Teori'ye (Bandura, 1986) dayanmaktadır. Bu boyut kişinin kendini motive edebilme, bilişsel kaynakları ve verilen işi başarıyla yerine getirebilme konusundaki yeteneklerine olan inancını ifade etmektedir (Stajkovic ve Luthans, 1998). Görüldüğü gibi psikolojik sermayenin bu boyutu bireyin becerilerinde ne derece yetkin olduğunu değil, becerilerine ne derece inandığını göstermektedir (Özkalp, 2009). Dolayısıyla özyeterlilik düzeyi yüksek olan bireyler kendi yeteneklerine güvenmektedirler. Bu da onların, zor görevlere talip olmalarına, amaçları uğrunda yılmadan zaman ve enerji harcamalarına, zorluklarla karşılaştıklarında sabırlı davranabilmelerine neden olmaktadır (Stajkovic ve Luthans, 1998).

Özyeterlilik, psikolojik sermayenin teorik desteği en fazla olan ve üzerinde en fazla araştırma yapılan boyutudur (Luthans,Youssef, Avolio, 2007: 16). Aynı zamanda yapılan araştırmalarda, özyeterlilik kapasitesinin iş performansı üzerinde önemli etki yaptığı ve iş ortamı içerisinde geliştirilebildiği tespit edilmiştir (Luthans, 2002a; b).

Ümit: Psikolojik sermayenin ikinci boyutu olan ümit, "olumlu bir motivasyon durumu olup, bireyin başarı duygusuna ulaşmasında onu amaca yönlendi- ren enerji ve yol" olarak tanımlanmaktadır (Snyder ve Lopez, 2007). Bu durumda boyut sadece bireyin kendisine ulaşılabilecek hedefler belirlemesini değil, aynı zamanda bu hedeflere gidecek yolu çizmesine ve bu yolda yürüyebilmek için kendi kendini motive edebileceğine olan inancını da ifade etmektedir.

Ümit boyutu iki alt boyutta incelenmektedir. Bu alt boyutlar ümidin var olabilmesi için gerekli olan istek gücü (bireyin hedefe ulaşma konusundaki isteği) ve bireyi istediği hedefe ulaştıracak yol gücü (bireyin hedefine ulaşmak için sarf edeceği enerji)dir (Snyder, Irving, Anderson, 1991). Bu iki alt boyut, bireyin psikolojik sermaye bakış açısı ile ümit kapasitesine sahip olarak görülmesi için gereklidir. Ümit boyutu diğer psikolojik sermaye boyutları gibi geliştirilebilir olmasının yanı sıra, doğuştan gelen bazı özellikleri de içerisinde barındırmaktadır (Snyder, Sympson, Ybasco, vd., 1996).

İyimserlik: İyimserlik kavramı, ilk bakışta ümit, güven gibi kavramlarla benzer gibi görülse de, yapılan araştırmalarda teorik ve ampirik açıdan diğerlerinden farklı özelliklere sahip olduğu ortaya konulmuştur (Bryant ve Cvengros, 2004; Magaletta ve Oliver, 1999). Psikolojik sermayenin kalbi olarak ifade edilen iyimserlik, yıllardır hem genel yaşamda hem de pozitif psikoloji içerisinde kullanılmaktadır (Luthans, 2002a).

İyimserlik en basit tanımıyla olumlu düşüncenin gücüdür. lyyimser bireyler kötü olayları dışsal ve tek seferlik olarak değerlendirirlerken; kötümser bireyler aksine aynı tür olayları içsel, sürekli ve genel olarak değerlendirmektedirler (Larson ve Luthans, 2006; Luthans, 2002a; Seligman, 1998). Buna göre bir sorun karşısında iyimser birey, sorunun kendisinden kaynaklanmadığını, normalde böyle bir sorun çıkmayacakken bu seferlik farklı dışsal sebeplerden dolayı çıktığını düşünerek, kötü durumu tek seferlik ve geçici olarak algılamaktadır. Diğer yandan kötümser birey aynı sorun karşısında, sorunun kendisinden kaynaklandığını, sürekli olarak sorunlarla karşılaştığını, ne yaparsa yapsın sonucun yine olumsuz olacağını düşünecektir.

Yapılan araştırmalarda iş performansı ile iyimserlik arasında doğrudan bir ilişki tespit edilmiştir (Schulman, 1999). Bunun nedeni iyimser bireylerin engelleri başarısızlık nedeni olarak görmemeleri, aksine başarı için geliştirilebilir fırsatlar ve meydan okumalar olarak algılamaları olabilir. Ayrıca iyimserliğin fiziksel ve psikolojik sağlığa, akademik, atletik, politik ve mesleki motivasyon ve başarıya etkileri üzerinde bir çok araştırma yapılmıştır (Luthans, 2008). Ancak iyimserliğin de bazı negatif yönleri, zararlı halleri ve maliyetleri 
vardır. Örneğin fiziksel olarak iyi bir insan gelecekteki sağlığı ile ilgili iyimser düşünecek ve alması gereken önlemleri almayabilecektir. Örgüt içerisinde ise iyimser bir yönetici, hedefe ulaşmak için yapması gereken kontrolleri yapmayabilecek ve alması gereken önlemleri almayabilecektir. Bu nedenle pozitif psikoloji daha gerçekçi ve daha esnek bir iyimserlik kavramına doğru kaymaktadır (Luthans, 2002a). Bu esnek (Peterson, 2000) ve gerçekçi (Schneider, 2001) iyimserlik ise psikolojik sermaye boyutu olan iyimserliğin tam karşılığıdır. Bu iyimserlik boyutunda karara varılmadan önce, pozitif ve negatif olaylar neden ve sonuçları ile birlikte detaylı olarak değerlendirilmelidir.

Dayanıklılık: Dayanıklıık kapasitesi psikolojik sermaye alt boyutları arasına sonradan dahil edilmiştir. Pozitif psikoloji içerisinde sıkça kullanılmakta olan bu kapasite, ancak 2002 yılından sonra psikolojik sermaye alt boyutu olarak kabul edilmiştir (Masten, 2001). Dayanıklılık "bireylerin değişim, zorluk ve risk durumlarının üstesinden başarı ile gelebilmelerini sağlayan pozitif psikolojik kapasitedir, bu kapasite zaman içerisinde değiş̧ebilir, bireysel ve çevresel faktörlerin etkisi ile geliştirilebilir" şeklinde tanımlanabilir (Stewart, 1997). Dayanıklılık sadece kötü olaylarla başa çıkabilme becerisi değildir, aynı zamanda aşırı pozitif olaylarla başa çıkabilmeyi de ifade etmektedir (Luthans,
Norman, Avolio, vd., 2008). Kısacası dayanıklılık, bireyi çevresindeki olumlu veya olumsuz olaylara karşı direncidir.

Psikolojik sermayenin diğer alt boyutlarından farklılaşan yönleri açısından bakıldığında, dayanıklıığı "pozitif psikoloji içerisinde bireyin risk ve olumsuz koşullar karşısında gösterdiği olumlu uyum" (Masten veReed, 2002) şeklinde tanımlamak mümkündür. Yapılan araştırmalar dayanıklılık kapasitesi ile iş performansı arasında pozitif yönlü bir ilişki tespit etmişlerdir. Buna göre hızla değişen iş dünyasında dayanıklılığı yüksek olan bireylerin, yaratıcı, değişime uyum sağlayan, terslikler ve engeller karşısında mücadeleci olmalarının performansları üzerinde olumlu etki yaptığı düşünülmektedir (Çetin ve Basım, 2012).

Yukarıda tanımlanan psikolojik sermaye boyutlarının tamamı, pozitif örgütsel davranış kavramlarının sahip olması gereken özelliklere uygun olarak; pozitif, kendilerine has, ölçülebilir, öğrenilebilir, geliştirilebilir niteliktedirler ve performansa olumlu etki yapma özelliği taşımaktadırlar (Luthans, 2002a). Ancak boyutların birbirlerine benzer yönlerinden dolayı çoğu zaman bu dört boyut birbirine karıştırılmaktadır. Aşağıdaki tablo dört boyutun yönlerini ve psikolojik sermayeye birbirilerinden farklı olarak sağladıkları katkıları göstermektedir.

Tablo 1:Psikolojik Sermaye Boyutlarının Yönleri ve Katkıları

\begin{tabular}{|l|l|l|}
\hline \multicolumn{1}{|c|}{ Boyut } & \multicolumn{1}{|c|}{ Yön } & \multicolumn{1}{c|}{ Katkı } \\
\hline Özyeterlilik & $\begin{array}{l}\text { Şimdiki zaman ve gelecek } \\
\text { odaklı }\end{array}$ & $\begin{array}{l}\text { Zorluklara karşı açık olmak ve amaç doğrultusunda çaba } \\
\text { sarfetme isteği }\end{array}$ \\
\hline Ümit & Gelecek odaklı & Amaçların oluşturulması ve bu amaçlara ulaşılması \\
\hline İyimserlik & Gelecek odaklı & $\begin{array}{l}\text { İstenmeyen olayların olumsuz etkilerine karşı koruma, } \\
\text { istenen olayların pozitif etkilerini artırma }\end{array}$ \\
\hline Dayanıklıık & $\begin{array}{l}\text { Geçmiş ve şimdiki zaman } \\
\text { odaklı }\end{array}$ & $\begin{array}{l}\text { Geçmişteki veya şimdiki zamandaki istenmeyen olayların, stres } \\
\text { faktörlerinin iyileştirilmesi ve mevcut durumun korunması }\end{array}$ \\
\hline
\end{tabular}

( Kaynak: Page ve Donohue,2004)

Psikolojik sermaye boyutlarından özyeterlilik ve ümit ilk etapta birbirinden ayırt edilememektedir, çünkü her ikisi de belirlenmiş amaca ulaşabilmek için bireyin içsel kaynaklarını kullanması ile ilişkilidir. Ancak tablodan da görüldüğü gibi ümit gelecek odaklı, özyeterlilik ise hem şimdiki zaman hem de gelecek odaklıdır. Ayrıca ümit sadece içsel kaynaklarla sağlanabiliyorken, özyeterlilik hem içsel hem de dışsal kaynaklarla sağlanabilmektedir. Diğer yandan özyeterlilik ve iyimserlik de birbirine benzer görünmektedir. İyimser bir birey de kendisini pozitif bir sonuç oluşturma konusunda özyeterliliğe sahip birey gibi yeterli görebilir, ancak özyeterlilik zorluk oluştuğu an geçerli bir özellikken, iyimserlik gelecek odaklıdır (Polatcı, 2011: 50).

Yukarıda psikolojik sermaye boyutlarının ayrı ayrı tanımları ve ayırt edici özellikleri üzerinde durulmuştur. Boyutların birbirinden farklı özellikleri olsa da, her biri toplam psikolojik sermayeye önemli katkılar sağlamaktadır. Yapılan araştırmalarda psikolojik sermaye boyutlarının birbirinden kavramsal olarak bağımsız oldukları tespit edilmiştir. Bu nedenle bazı araştırmalarda psikolojik sermaye boyutlar bazında ele alınarak incelenmiştir (Luthans, Youssef, Avolio, 2007; Çetin ve Basım, 2012; Luthans, Avolio, Walumbwa, vd., 2005). 
Bu bilgiler ışığında, aşağıdaki hipotezlergeliştirilmiştir:

Hipotez 2a: Psikolojik sermayenin alt boyutları (özyeterlilik, ümit, iyimserlik, dayanıklılık) toplam performansı pozitif yönde etkilemektedir.

Hipotez 2b: Psikolojik sermayenin alt boyutları (özyeterlilik, ümit, iyimserlik, dayanıklılık) görev performansını pozitif yönde etkilemektedir.

Hipotez 2c: Psikolojik sermayenin alt boyutları (özyeterlilik, ümit, iyimserlik, dayanıkııık) bağlamsal performansı pozitif yönde etkilemektedir.

\section{YÖNTEM}

\subsection{Araştırmanın Anakütle ve Örneklemi}

$\mathrm{Bu}$ araştırmanın ana kütlesini Tokat ilinde görev yapmakta olan polis memurları oluşturmaktadır. Zaman ve maliyet kısıtları dolayısıyla ana kütleyi temsil yeteneği olan bir örneklem büyüklügü belirlenmesinin uygun olduğu düşünülmüştür. Araştırmada örnekleme çerçevesine ulaşmak mümkün olmadığından dolayı tesadüfi olmayan örnekleme yöntemlerden kolayda örneklemeye başvurulmuştur. Araştırmada 180 polis memuruna anketformu dağıtılmış, 150 geri dönüş elde edilmiştir. Geri dönen anket formlarından 134 anket analize tabi tutulmuştur. Analize tabi tutulan katılımcıların demografik özelliklerine ilişkin bilgiler Tablo 2'de görülmektedir.

Tablo 2:Katılımcıların Demografik Özelliklerine İlişkin Bilgiler

\begin{tabular}{|l|c|c|l|c|c|}
\hline Cinsiyet & $\mathrm{f}$ & $\%$ & Kurumdaki Kıdem & $\mathrm{f}$ & $\%$ \\
\hline Kadın & 21 & 15,7 & $0-5$ & 84 & 62,7 \\
\hline Erkek & 113 & 84,3 & $6-10$ & 25 & 18,6 \\
\hline Yaş & $\mathrm{f}$ & $\%$ & $11-15$ & 15 & 11,2 \\
\hline $26-35$ & 61 & 45,5 & $16-20$ & 10 & 7,5 \\
\hline $36-45$ & 62 & 46 & İdari görev & $\mathrm{f}$ & $\%$ \\
\hline 45 ve üzeri & 11 & 8,5 & Var & 49 & 36,6 \\
\hline Eğitim & $\mathrm{f}$ & $\%$ & Yok & 85 & 63,4 \\
\hline Lise & 10 & 7,5 & Medeni Durum & $\mathrm{f}$ & $\%$ \\
\hline Önlisans & 52 & 38,8 & Evli & 125 & 93,3 \\
\hline Lisans & 65 & 48,5 & Bekar & 9 & 6,7 \\
\hline Lisansüstü & 7 & 5,2 & Çocuk sayıs1 & $\mathrm{f}$ & $\%$ \\
\hline $\begin{array}{l}\text { M e s I e k i } \\
\text { Kıdem }\end{array}$ & $\mathrm{f}$ & $\%$ & Yok & 15 & 11,2 \\
\hline $0-5$ & 21 & 15,6 & 1 & 34 & 25,4 \\
\hline 6-10 & 26 & 19,4 & 2 & 64 & 47,8 \\
\hline $11-15$ & 62 & 46,3 & 3 ve üzeri & 12 & 8,9 \\
\hline $16-20$ & 13 & 9,7 & Toplam (Evliler) & 125 & 93,3 \\
\hline 21 ve üzeri & 12 & 9 & & & \\
\hline
\end{tabular}

Yukarıdaki tabloda da görüldüğü gibi, araştırmaya katılan polislerin yaklaşık \%84'ü erkek, \%16'sı kadındır. Katılımcıların yaklaşık \%46'sı 26-35, \%46'sı 36-45 yaş aralığındadır. Eğitim durumlarına bakıldığında yaklaşık \%49'unun lisans, \%39'unun önlisans mezunu oldukları görülmektedir. Meslek hayatında geçen zaman açısından yaklaşık \%46'sının 11-15 yıldır emniyet teşkilatı içerisinde görev yaptığı ve $\% 62,7$ gibi büyük bir bölümünün şu anda bulundukları birimdeki ilk 5 yıllarının içerisinde oldukları tespit edilmiştir. Ayrıca araştırmaya katılan polislerin \%36,6'sının idari görevi bulunmaktadır. Polis memurlarının \%93,3'ünün evli ve \%47,8'inin 2 çocuk sahibi olduğu araştırma sonucunda ortaya çıkmıştır.

\subsection{Veri Toplama Araçları}

Araştırmada veri toplama amacıyla anket formu kullanılmıştır. Anket formu üç bölümden oluşmaktadır. Illk iki bölümde psikolojik sermaye ve performans ölçekleri yer alırken, son bölümde katılımcıların demografik özelliklerini belirlemeye yönelik sorular yer almaktadır. Araştırmada katılımcıların anket formundaki ifadelere katılım düzeylerini belirlemek amacıyla 5'li likert tipi ölçek kullanılmıştır ( $1=$ Kesinlikle Katılmiyorum, 2 = Katılmıyorum, $3=$ Ne katılıyorum ne katılmıyorum, 4 = Katılıyorum, $5=$ Kesinlikle Katılıyorum). Anket formunda yer alan ölçeklerle ilgili bilgiler aşağıda verilmiştir.

Psikolojik Sermaye Ölçeği: İşgörenlerin psikolojik sermaye düzeylerini tespit etmek amacıyla Luthans ve arkadaşları tarafından geliştirilmiş olan psikolojik sermaye ölçeği (Luthans; Youssef; Avolio, 2007; 237) kullanılmıştır. Ölçek psikolojik sermaye kavramının 4 boyutunu 24 ifade ile ölçmektedir. Ölçekte ilk 6 ifade özyeterlilik boyutunu; $7,8,9,10,11$ ve 12. ifadeler ümit boyutunu; $13,14,15,16,17$ ve 18 . ifadeler dayanıklılık boyutunu ve 19, 20, 21, 22, 23 ve 24 . ifadeler ise iyimserlik boyutunu ifade etmektedir. Cevapların tutarlılığını kontrol etmek amacıyla ters ifadeler (13, 20, 23) kullanılmıştır. Bu ifadeler analizlere başlanmadan önce ters çevrilerek ortalamaya dahil edilmiştir. Ölçeğe ait alt boyutların ayrı ayrı güvenilirlik katsayıları (özyeterlilik 0,86; ümit 0,75; dayanıklılık 0,82 ve iyimserlik 0,69 ) ve genel olarak psikolojik sermaye ölçeğinin güvenilirlik katsayısına $(0,91)$ bakıldığında, ölçek güvenilirliğinin kabul edilebilir sınırlar içerisinde olduğu görülmektedir (Nakip, 2006: 146).

Performans Ölçeği: Araştırmada Goodman ve Svyantek $(1999 ; 261)$ tarafından geliştirilmiş olan 25 ifadeli performans ölçeği kullanılmıştır. Bu ölçeğin ilk 16 ifadesi bağlamsal performansı ifade ederken, son 9 ifade ise görev performansını ifade etmektedir. Ölçekte 4,8 ve 10. ifadeler ters ifadeler olması sebebiyle, analize dahil ederken bu ifadeler ters çevrilerek analize dahil edilmiştir. Bağlamsal performans alt boyutu- 
nun güvenilirlik katsayısı 0,91, görev performansı alt boyutunun güvenilirlik katsayısı 0,91 ve performans ölçeğinin tamamının güvenilirlik katsayısı ise 0,93 olarak belirlenmiştir.

\section{VERILERIN ANALIZi}

Araştırmada değişkenlere ilişkin tanımlayıc istatistikler, güvenilirlik analizleri, korelasyon analizi ile araştırma hipotezlerinin testine yönelik regresyon analizi kullanılmıştır. Verilerin analizine başlamadan önce verilerin analize hazırlanması amacıyla bazı işlemler yapılmıştır. Bu işlemler eksik anket formlarının kontrolü, eksik değer analizi ve normallik analizleridir.

\subsection{Araştırmanın Bulguları}

Araştırma değişkenlerine ait ortalama, standart sapma değerleri ve korelasyon katsayıları Tablo 3'te verilmiş̧ir.

Tablo 3: Değişkenlere Iliş̧kin Tanımlayıcı İstatistikler ve Korelasyon Katsayıları

\begin{tabular}{|l|l|l|l|l|l|l|l|l|l|}
\hline & Ort. & SS & 1 & 2 & 3 & 4 & 5 & 6 & 7 \\
\hline 1.Özyeterlilik & 4,31 &, 544 & 1 & & & & & & \\
\hline 2.Ümit & 4,08 &, 578 &, $550^{* *}$ & 1 & & & & & \\
\hline 3.Dayanıklılık & 4,01 &, 582 &, $646^{* *}$ &, $605^{* *}$ & 1 & & & & \\
\hline 4.Iyimserlik & 3,86 &, 823 &, 177 &, $391^{* *}$ &, $249^{*}$ & 1 & & & \\
\hline 5. Psikolojik Sermaye & 4,06 &, 473 &, $731^{* *}$ &, $820^{* *}$ &, $787^{* *}$ &, $682^{* *}$ & 1 & & \\
\hline 6.Bağlamsal perf. & 4,20 &, 537 &, $508^{* *}$ &, $478^{* *}$ &, $574^{* *}$ &, 183 &, $549^{* *}$ & 1 & \\
\hline 7.Görev perf. & 4,10 &, 546 &, $441^{* *}$ &, $513^{* *}$ &, $553^{* *}$ &, $226^{*}$ &, $552^{* *}$ &, $586^{* *}$ & 1 \\
\hline 8. Performans & 4,15 &, 482 &, $533^{* *}$ &, $557^{* *}$ &, $633^{* *}$ &, $230^{*}$ &, $618^{* *}$ &, $888^{* *}$ &, $892^{* *}$ \\
\hline
\end{tabular}

( Not: $\left.{ }^{*} p<0.05 * * p<0.01\right)$

Tablodaki ortalama değerlere bakıldığında katılımcıların hem psikolojik sermaye hem de performans açısından kendilerini ortalamanın üzerinde değerlendirdiklerini söylemek mümkündür.

Tablo 3 incelendiğinde psikolojik sermaye boyutlarından özyeterlilik ile iyimserlik arasında ve iyimserlik ile bağlamsal performans arasında istatistiki açıdan anlamlı ilişkinin olmadığı görülmektedir. Bunlar dışındaki diğer tüm korelasyon değerleri 0,01 ve 0,05 düzeyinde ve pozitif yönde anlamlıdır. Psikolojik sermaye ve performans alt boyutlarının birbirleri arasında orta düzeyde ve anlamlı ilişkiler göze çarpmaktadır. Ayrıca psikolojik sermayenin tüm alt boyutlarının ve genel psikolojik sermaye düzeyinin performans ile ilişkili olduğu belirlenmiştir.
Değişkenler arasındaki korelasyon analizinin yanı sıra, bağımlı ve bağımsız değişkenlerin katılımcıların demografik özellikleri açısından farklılaşıp farklılaşmadıklarına da bakılmıştır. Yaş, cinsiyet, eğitim durumu, meslekteki ve şu anda çalışılan birimdeki kıdem gibi demografik özellikler açısından araştırmada yer alan değişkenlerin istatistiksel olarak anlamlı düzeyde farklılık göstermediği tespit edilmiştir.

\subsection{Hipotez Testleri}

Hipotez $1 \mathrm{a}, 1 \mathrm{~b}$ ve $1 \mathrm{c}$ genel psikolojik sermaye düzeyinin toplam performans, görev performansı ve bağlamsal performans üzerinde pozitif yönde etkili olduğunu öngörmekte idi. Bu hipotezleri test edebilmek için genel psikolojik sermaye düzeyi toplam performans, görev performansı ve bağlamsal performans ile ayrı ayrı regresyon analizine tabi tutulmuştur.

Tablo 4:Psikolojik Sermaye ve Performans Arasındaki Regresyon Analizi

\begin{tabular}{|l|c|c|c|}
\hline & Toplam Performans & Görev Performansı & Bağlamsal Performans \\
\hline Psikolojik Sermaye & $0.618^{* *}$ & $0.552^{* *}$ & $0.549^{* *}$ \\
\hline F & $63.074^{* *}$ & $44.755^{* *}$ & $43.907^{* *}$ \\
\hline Düzeltilmiş $\mathrm{R}^{2}$ & 0.376 & 0.298 & 0.294 \\
\hline
\end{tabular}

Tablo 4'te görüldüğü gibi psikolojik sermaye toplam performansı $(\beta=0.618, p<0.01)$ ve performansin her iki alt boyutunu $(\beta=0.552$ ve $\beta=0.549, p<0.01)$ pozitif yönde etkilemektedir. Ayrıca psikolojik sermaye bir bütün olarak toplam performansın varyansının yaklaşık \%38'ini, görev performansının yaklaşık 
\%30'unu ve bağlamsal performansın \%29'unu açıklamaktadır. Bu bilgiler ışı̆̆ında Hipotez 1a, 1b ve 1c kabul edilmiştir.

Hipotez 2a'yı test etmek için yapılan regresyon analizinde psikolojik sermayenin ayrı ayrı alt boyutlarının toplam performans üzerindeki etkileri incelenmiştir.

Tablo 5: Regresyon Analizi Tablosu

\begin{tabular}{|l|c|}
\hline & Toplam Performans \\
\hline Özyeterlilik & 0.149 \\
\hline Ümit & $0.231^{*}$ \\
\hline Dayanıklılık & $0.393^{* *}$ \\
\hline İyimserlik & 0.015 \\
\hline F & $21.120^{* *}$ \\
\hline Düzeltilmiş $\mathrm{R}^{2}$ & 0.439 \\
\hline
\end{tabular}

( Not: ${ }^{*} p<0.05{ }^{* *} p<0.01$ )

Analiz sonuçlarına göre psikolojik sermayenin alt boyutları toplam performanstaki değişimin yaklaşık $\% 44$ 'ünü açıklamaktadır $\left(R=0.679, R^{2}=0.439, p<0.01\right)$. Modelin geçerliliğini test etmek için yapılan ANOVA testinde elde edilen $F$ değeri $21.120(p<0.01)^{\prime}$ 'dir. Bu değerle modelin $p<0.01$ düzeyinde anlamlı olduğu sonucuna varılmıştır.

Tablo 5 aynı zamanda, bağımsız değişken olarak ayrı ayrı alt boyutlarının toplam performansı yordama gücünü test etmek üzere, standardize edilmiş regresyon katsayıları ( $\beta$ ) ve anlamlılığa ilişkin $p$ değerleri ile ilgili bilgileri içermektedir. Standardize edilmiş regresyon katsayılarına göre psikolojik sermayenin alt boyutları açısından bakıldığında sadece ümit $(0.231$, $\mathrm{p}<0.05)$ ve dayanıklılık $(0.393, p<0.01)$ alt boyutlarının performansı yordadıkları görülmektedir. Bu bilgiler ışığında psikolojik sermaye değişkeninin alt boyutlarından ümit ve dayanıklılığın toplam performans üzerinde pozitif yönde etkili olduğu, diğer iki alt boyutun ise toplam performans üzerinde anlamlı etkiye sahip olmadığı tespit edilmiştir. Buna göre H2a hipotezi reddedilmiştir.

Toplam performans düzeyi üzerinde psikolojik sermaye alt boyutlarının etkilerini belirledikten sonra, bu alt boyutların performansın iki farklı boyutu olan görev performansı ve bağlamsal performans üzerindeki etkileri de incelenmiştir.
Tablo6: Hiyerarşik Çoklu Regresyon Analizi

\begin{tabular}{|l|l|l|}
\hline & Görev Performans & Bağlamsal Performansı \\
\hline Özyeterlilik & 0.075 & 0.192 \\
\hline Ümit & $0.252^{*}$ & 0.159 \\
\hline Dayanıklılık & $0.345^{* *}$ & $0.355^{* *}$ \\
\hline İyimserlik & 0.028 & -0.002 \\
\hline F & $13.900^{* *}$ & $14.968^{* *}$ \\
\hline Düzeltilmiş $\mathrm{R}^{2}$ & 0.334 & 0.352 \\
\hline ( Not: $\left.{ }^{*} \mathrm{p}<0.05^{* *} \mathrm{p}<0.01\right)$ &
\end{tabular}

Görev performansındaki toplam varyansın yaklaşık \%33'ü psikolojik sermayenin alt boyutları $\left(R=0.600, R^{2}=0.334, p<0.01\right)$ tarafından açıklanmaktadır. Model geçerliliği ANOVA testi ile ölçülmüş ve modelin anlamlı olduğu görülmüştür ( $F=13.900$, $\mathrm{p}<0.01)$. Standardize edilmiş regresyon katsayılarına bakıldığında psikolojik sermayenin alt boyutlarından ümit $(0.252, p<0.05)$ ve dayanıklılı̆ın $(0.355, p<0.01)$ görev performansını anlamlı ve pozitif yönde etkilediği görülmektedir. $\mathrm{H} 2 \mathrm{~b}$ reddedilmiştir.

Psikolojik sermayenin alt boyutları performansın diğer bir boyutu olan bağlamsal performanstaki toplam varyansın yaklaşık \%35'ini $\left(R=0.614, R^{2}=0.352\right.$, $\mathrm{p}<0.01$ ) açıklamaktadır. Model geçerliliği ANOVA testi ile ölçülmüş ve modelin anlamlı olduğu görülmüştür $(F=14.968, p<0.01)$. Standardize edilmiş regresyon katsayılarına göre psikolojik sermayenin alt boyutları açısından bakıldığında sadece dayanıklılık (0.355, $\mathrm{p}<0.01)$ alt boyutunun bağlamsal performansı anlamlı ve pozitif yönde etkilediği görülmektedir. $\mathrm{H} 2 \mathrm{c}$ reddedilmiştir.

\section{SONUÇ VE ÖNERILER}

Bu çalışmanın amacı psikolojik sermaye ve alt boyutlarının, polis memurlarının performanslarını açıklamada ne derece etkin olduklarını anlamak ve sahip olunan psikolojik sermayenin polislerini görev ve bağlamsal performans düzeyleri üzerindeki etkisini belirlemektir. Bu amaç doğrultusunda Tokat II Emniyet Müdürlüğü'ne bağlı, merkez ilçede görev yapan polis memurlarının psikolojik sermaye ve performans düzeyleri ile ilgili veri toplanmıştır. Toplanan veriler regresyon ile çözümlenmiştir.

Genel psikolojik sermaye düzeyinin toplam performans ve performansın iki alt boyutu üzerinde pozitif yönde etkili olduğu tespit edilmiştir. Ulaşılan sonuçlara göre, genel psikolojik sermaye düzeyi bir bütün olarak ele alındığında bağlamsal ve görev performansınınayrı ayrı \%30'unu, toplam performansın ise yaklaşık \%38'ini açıklamaktadır. Psikolojik sermayenin alt boyutları açısından bakıldığında ise, performansın \%44'ünü, görev performansının \%33'ünü, bağlamsal 
performansın ise $\% 35^{\prime}$ ini açıkladığı görülmüştür. Elde edilen sonuçlar literatür ile paralellik göstermektedir.

Psikolojik sermayenin performans üzerindeki etkileri incelendiğinde ise, toplam psikolojik sermayenin toplam performansı ve performansın her iki boyutunu pozitif ve anlamlı düzeyde etkilediği görülmüştür. Bu analiz psikolojik sermayenin alt boyutları düzeyinde yapıldığında ise, sadece dayanıklılık alt boyutunun hem toplam performansı hem de iki performans boyutunu anlamlı ve pozitif yönde etkilediği, ümit alt boyutunun ise toplam performansı ve görev performansını anlamlı ve pozitif yönde etkilediği tespit edilmiştir. Diğer boyutlarda ise anlamlı bir etki görülmemiştir.

Araştırmanın en önemli sonucu psikolojik sermaye ve alt boyutları arasında performans ve boyutları üzerindeki etki açısından bir farklılı̆ın tespit edilmiş olmasıdır. Toplam psikolojik sermaye performans üzerinde önemli ölçüde etkili olurken, psikolojik sermayenin tüm alt boyutları performans üzerinde aynı şekilde etkili olmamaktadır. Buna göre araştırmacıların, psikolojik sermaye ölçümünde toplam psikolojik sermaye ve alt boyutlar arasındaki farklılıkları gözardı etmemeleri gerekmektedir.

Diğer bir önemli sonuç ise bağlamsal performans üzerinde, psikolojik sermaye alt boyutlarından sadece dayanıklılığın, görev performansı üzerinde ise ümit ve dayanıkııı̆ıı etkili olduğudur. Alt boyutların toplam performans üzerindeki etkilerine bakıldığında da, psikolojik sermaye alt boyutlarından yine ümit ve dayanıklılığın etkili olduğu görülmektedir. Bu sonuçlarda literatürle paralellik göstermektedir (Rego, Marques, Leal, vd., 2010). Özyeterlilik ve iyimserlik hiçbir durumda performans üzerinde anlamlı etki göstermemiştir. Diğer bir deyişle polislerin becerilerine olan inançları ve olumlu düşünebilme güçleri, onların performanslarını etkilememektedir. Özellikle dayanıklıık alt boyutunun performans üzerindeki etkisinin öne çıkmasının, polislik mesleğinin tehlikeli, zor ve çok fazla fedakarlık isteyen bir iş olmasından kaynaklandığı düşünülmektedir.

Sonuç olarak elde edilen bulgular ışığında polis memurlarının psikolojik sermaye düzeylerindeki gelişmelerin performansları üzerinde ciddi bir olumlu etkiye neden olacağı ortaya konulmuştur. Emniyet güçlerinin performanslarını artırmak için, psikolojik sermayenin özellikle dayanıklılık ve ümit alt boyutunda polislere verilen maddi ve manevi desteğin artırılması faydalı olacaktır.

\section{- Araştırmanın Kısıtları ve İlerideki Çalışmalara Yönelik Öneriler}

İlerleyen çalışmalarda aynı değişkenler farklı meslek gruplarında ölçülerek, değişkenler açısından meslekler arasındaki farklııklar incelenebilir. Ayrıca polisler üzerinde daha geniş örneklemlerde, daha detaylı araştırmaların yapılması da mümkündür. $\mathrm{Bu}$ çalışmada performans ölçümünde tamamen, katılımcıların beyanları esas alınmıştır, daha sonraki çalışmalarda üst yönetimin performans değerlendirmeleri de araştırmaya dahil edilebilir.

Bu çalışmada, ortaya konulmuş olan amaç dahilinde psikolojik sermayenin performans üzerindeki etkisi incelenmiştir, ilerleyen çalışmalarda farklı değişkenler bu ilişkiye dahil edilerek analiz derinleştirilebilir. Örneğin örgütsel faktörlerden örgütsel destek, örgütsel adalet; bireysel faktörlerden kişilik özellikleri, kontrol odağı, pozitif negatif duygusallık gibi faktörlerin bu ilişkiye dahil edilmesi mümkün olabilir. 


\section{KAYNAKLAR}

Akdoğan, A. ve Polatc1, S. (2013) "Psikolojik Sermayenin Performans Üzerindeki Etkisinde İş Aile Yayılımı ve Psikolojik İyi Oluşun Etkisi”, Atatürk Üniversitesi Sosyal Bilimler Fakültesi Dergisi, 17(1):273-293.

Bandura, A. (1986)Social Foundations of Thought and Action, Englewood Cliffs, New Jersey, Prentice Hall.

Borman, W.C. ve Motowidlo S.J. (1993) "Expanding the Criterion Domain to Include Elements of Contextual Performance," Schmitt et all(eds.)Personnel Selection in Organizations, San Francisco, Jossey-Bass.

Bryant, F.B. ve Cvengros, J.A. (2004) "Distinguishin gHopeandOptimism"Journal of SocialandClinicalPsycho$\log y, 23: 273-302$.

Çetin, F. ve Basım, N. (2012) "Örgütsel Psikolojik Sermaye: Bir Ölçek Uyarlama Çalışması” Amme İdaresi Dergisi, 45(1):121-137.

Envick, B.R. (2005) "Beyond Humand and Social Capital: The Importance of Positive Psychological Capital for Entrepreneurial Success" The Entrepreneurial Executive, $10: 41-52$

Goodman, S.A. ve Svyantek, D.J. (1999) "Person-Organization Fit and Contextual Performance: Do Shared Values Matter" Journal Of Vocational Behavior, 55:254-275

Jawahar, I.M. ve Carr, D. (2007) "Conscientiousness and Contextual Performance: The Compensatory Effects of Perceived Organizational Support and Leader-Member Exchange" Journal of Managerial Psychology, 22(4):330349.

Larson, M. ve Luthans, F. (2006) "Potential Added Value of Psychological Capital in Predicting Work Attitudes"Journal of Leadership and Organizational Studies, 13(1):45- 62.

Luthans, F., Avolio, B.J., Avey, J.B. ve Norman, S.M. (2007) "Positive Psychological Capital: Measurement and Relationship with Performance and Satisfaction" Personnel Pschology, 60:541-572.

Luthans, F., Avolio, B.J., Walumbwa, F.O. ve Li, W. (2005) "The Psychological Capital of Chinese Workers, Exploring the Relationship with Performance," Management and Organization Review, 1(2):249-271.

Luthans, F., Youssef, C.M. ve Avolio, B.J. (2007) Psychological Capital, Oxford, Oxford University Press.

Luthans, F. ve Avolio, B.J. (2009) “'The Point' of Positive Organizational Behavior" Journal of Organizational Behavior, 30:291-307.

Luthans, F. (2002a) "Positive Organizational Behavior: Developing and Managing Psychological Strengths" Academy of Management Executive, 15(1):57-72.
Luthans, F. (2002b) "The Need for and Meaning of Positive Organizational Behavior" Journal of Organizational Behavior, 23:695-706.

Luthans, F., Youssef, C.M. ve Avolio, B.J. (2007) Psychological Capital, New York, Oxford University Press.

Luthans, F., Luthans, K.W. ve Luthans, B.C. (2004) "Positive Psychological Capital: Beyond Human and Social Capital" Business Horizons, 47(1):45-50.

Luthans, F. (2008) Organizational Behavior, 11. Edition, McGraw Hill.

Luthans, F., Norman, S.M., Avolio, B.J.ve Avey, J.B. (2008) "The Mediating Role of Psychological Capital in the Supportive Organizational Climate-Employee Performance Relationship" Journal of Organizational Behavior, 29:219-238.

Magaletta, P.R. ve Oliver, J.M. (1999) "TheHopeConstruct, Will, andWays: TheirRelationswithEfficacy, Optimism, and General Well-being", Journal of ClinicalPsychology, 55(5): 539-551.

Masten, A.S. ve Marie-Gabrielle J.R. (2002) "Resilience in Development" Snyder et al (eds.) Handbook of Positive Psychology, Oxford, Oxford University Press.

Masten, A.S. (2001) "Ordinary Magic: Resilience Process in Development" American Psychologist, 56(3):227-239.

Motowidlo, S.J. (2000) "Some Basic Issues Related to Contextual Performance and Organizational Citizenship Behavior in Human Resource Management" Human Resource Management Review, 10(1):115-126.

Nakip, M. (2006) Pazarlama Araştırmalar Teknikler ve Uygulamalar,Ankara, Seçkin Yayıncılık.

Nelson, D. ve Cooper, C.L. (2007)Positive Organizational Behavior, London, Sage Publication.

Özkalp, E. (2009) “Örgütsel Davranışta Yeni Bir Boyut: Pozitif (Olumlu) Örgütsel Davranış Yaklaşımı ve Konuları”Osmangazi Üniversitesi, Eskişehir17. Ulusal Yönetim ve Organizasyon Kongresi Bildiri Kitabı,491-497.

Page L.F. ve Donohue, R. (2004) "Positive Psychological Capital: A Preliminary Exploration of the Construct" Monash University Department of Management Working Paper Series.

Peterson, C. (2000) "The Future of Optimism”American Psychologist, 55(1) 44-55.

Polatc1, S. (2011) "Psikolojik Sermayenin Performans Üzerindeki Etkisinde İş Aile Yayılımı ve Psikolojik İyi Oluşun Rolü” Yayınlanmamış Doktora Tezi,Kayseri, Erciyes Üniversitesi Sosyal Bilimler Enstitüsü. 
Rego, A., Marques, C., Leal, S., Sousa, F. ve Cunha, M.P. (2010) "Psychological Capital and Performans of Portugese Civil Servants: Exploring Neutralizers in the Context of an Appraisal System" The International Journal of Human Resource Management, 21(9):1531-1552.

Schneider, S.L. (2001) "In Search of Realistic Optimism: Meaning, Knowledge and Warm Fuzziness"American Psychologist, 56(3):250-263.

Schulman, P. (1999) "Applying Learned Optimism to Increase Sales Productivity" Journal of Personal Selling and Sales Management, 19(1):31-37.

Seligman, M. ve Csikszentmihalyi, M. (2000) "Positive Psychology" American Psychologist, 55(1):5-14.

Seligman, M. (1998)LearnedOptimism, New York, Pocket Books.

Snyder, C.R. ve Lopez, S.J. (2007)Positive Psychology: The Scientific and Practical Explorations of Human Strengths, USA, Sage Publication.
Snyder, C.R., Irving, L.M. veAnderson, J.R. (1991) "Hope and Health: Measuring the Will and the Ways" Snyder et al.(eds.) Handbook of Social and Clinical Psychology, New York, Pergamon.

Snyder, C.R., Sympson, S.C., Ybasco, F.C., Borders, T.F., Babyak, M.A. ve Higgins, R.L. (1996) "Development and Validation of the State Hope Scale" Journal of Personality and Social Psychology, 70(2):321-335.

Stajkovic, A.D. ve Luthans, F. (1998) "Social Cognitive Theory and Self-Efficacy: Going Beyond Traditional Motivational and Behavioral Approaches"Organizational Dynamics, 26(4): 62-74.

Stewart, M.,Reid, G. ve Mangham, C. (1997) "Fostering Children's Resilience" Journal of Pediatric Nursing, 12(1):21-31.

Youssef, C.M. ve Luthans, F. (2007) "Positive Organizational Behavior in the Workplace: The Impact of Hope, Optimism, and Resiliency"Journal of Management, 33:774-800. 